\title{
TWU SERIES
}

\section{THE WORLd BANK}

\section{Private Sector Development and Infrastructure}

TWU-40

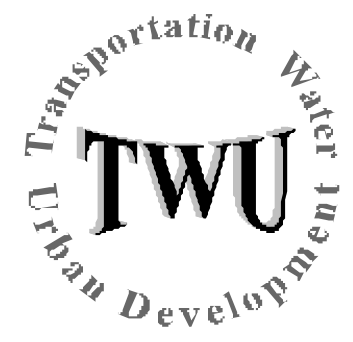

Transport Division

Private Participation in Public Transport in the FSU

Kenneth M. Gwilliam

\section{Discussion Paper \\ April 2000}

This is a document published informally by the World Bank. The views and interpretations herein are those of the author and should not be attributed to the World Bank, to its affiliated organizations, or to any individual acting on their behalf. 



\title{
Private Participation in Public Transport in the FSU
}

\author{
Kenneth M. Gwilliam ${ }^{1}$ \\ Principal Transport Economist \\ The World Bank \\ CONTENTS
}

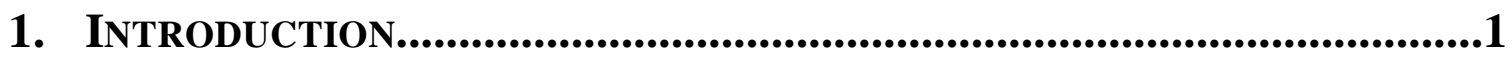

2. THE CONTEXT FOR PRIVATE SECTOR DEVELOPMENT ............................1

2.1 The pre-liberalization regime ..................................................................

1.2 The immediate effects of liberalization...........................................................

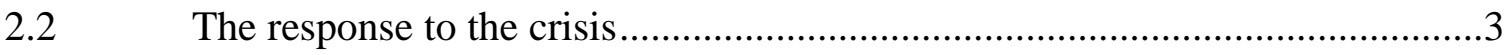

3. THE EMERGENCE OF A NEW PRIVATE SECTOR.....................................3

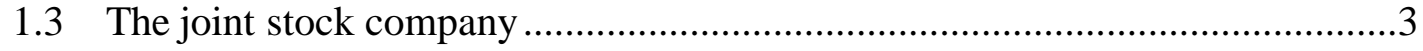

2.3 The independent operator and operators associations ........................................

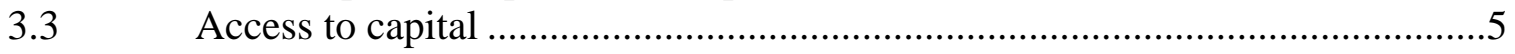

4. THE REGULATORY REFORMS .........................................................6

1.4 Entry to the market.............................................................................6

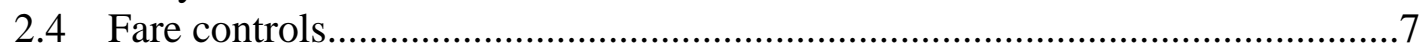

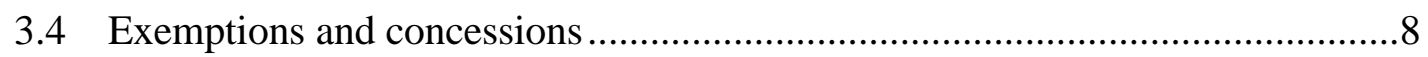

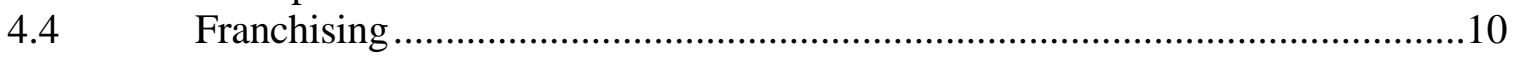

5. PROSPECTS FOR THE FUTURE ..........................................................13

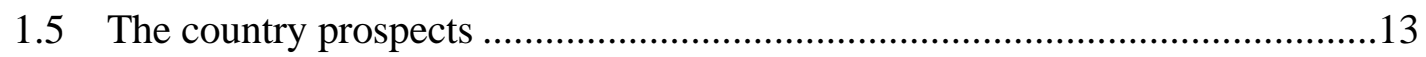

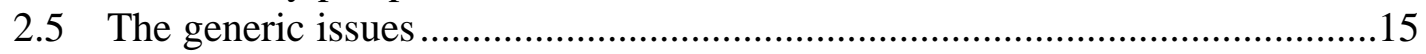

1 The views expressed in this paper are those of the author and should not be attributed to the World Bank or its affiliated organizations. I am indebted to numerous colleagues including Oleg Borokovic, Maurice Dickerson, Richard Podolske, Kavita Sethi and Graham Smith for their contribution of information. 


\section{Introduction}

This paper describes and analyses the growth of private sector participation in public transport supply in the countries in the Former Soviet Union in which the World Bank has had recent sector involvement. This includes Russia, Ukraine, Latvia, Kazakhstan, Uzbekistan, Kyrgyz S.R. and Turkmenistan. While this does not covers only 7 out of the 15 independent states comprising the former, this sample of countries accounts for over $96 \% \%$ of the land area and $85 \%$ of the population of the FSU. It also includes a wide spectrum of countries in terms of size, reform philosophy and income levels. The region only contains two megacities with populations in excess of 5 million (Moscow and St Petersburg) but has many cities in the range of 0.5 to 2.0 million.

\section{The context for private sector development}

\subsection{The pre-liberalization regime}

Under the socialist system responsibility for road transport was very centralized under a transport ministry in each of the republics. Usually there would be a division of the central agency at each oblast level which effectively services and controlled the operations of the vehicle parks. In most cases these parks would contain urban and inter-urban buses, and often freight vehicles as well. They would typically provide a range of social and medical services for employees and their families.

Operations were very non-commercial. A large proportion of passengers would be carried free or at reduced rates (up to $80 \%$ in the latter years of the public enterprise of Rostov on Don in Russia). Accounting systems were also typical of the socialist system, being based on cash flow rather than accruals. Though historic depreciation was recorded in the books no depreciation reserves were maintained and capital was obtained as a grant from the state.

Many city systems have trams and/or trolleybuses. These were often the responsibility of a different ministry from the buses. Metros are also common, it having been a norm under the socialist system that cities of more than 1 million population merited a metro system. However, analysis of the results of the Russian cities shows a strong negative correlation between the financial performance of the city transport systems and the existence of a fixed route system.

\subsection{The immediate effects of liberalization}

In real terms incomes fell between $30 \%$ and $60 \%$ in the first two or three years after liberalization. ${ }^{2}$ Although the official figures may overstate the magnitude of the impact on real living standards due to both the overstatement of outputs pre-liberalization and to the understatement of personal and informal sector incomes post liberalization, it is clear that the declines in income were large, long lasting, ${ }^{3}$ and widely distributed. ${ }^{4}$ In some countries

\footnotetext{
${ }^{2}$ Milanovic, B. Income, Inequality and Poverty During the Transition from the Planned to the Market Economy. Regional and Sectoral Studies. World Bank. 1998

${ }^{3}$ By 1994 almost all of the non-FSU post-communist countries were growing again while by the same date only Armenia, Latvia and Lithuania of the FSU countries had tuned the corner. Milanovic. op. cit.
} 
hyperinflation developed, with particularly adverse consequences on public sector industries operating with regulated prices. Deteriorating finances due to adjustment lags were normal. In Turkmenistan, at one period there was no coinage equivalent to the basic fare. Consequently an increasing proportion of passengers did not pay fares at all, and cost recovery fell to $2 \%$ of costs.

The reduction of income was accompanied by a loss of employment which in its turn reduced public transport demand. The sectors to suffer worst were in many cases the heavy industries which had generated large, concentrated passenger flows. Longer term structural change has also contributed to a reduction in the concentration of flows, to the disadvantage of large vehicle trunk routes, and to the advantage of the more flexible smaller vehicles operated by the informal sector.

At the same time that the public sector transport countries were losing patronage and farebox income they were also losing their traditional public income source with the disappearance of the major state enterprises from which fiscal revenue was primarily derived.

The immediate effect of the post liberalization crisis was a loss of revenue for vehicle replacement and maintenance. While this could be tolerated for a time, eventually it led to a reduction in vehicle availability, increases in failures in service and eventually a decline in the total vehicle stock. For example, the public sector fleet in Bishkek in Kyrgyzstan, fell from 470 to 372 over the year to October, 1997. Only 250 of these vehicles were operational and on average only 180 were turned out each day for peak service. Similarly, the available stock of vehicles in the public sector companies has been declining at a rate of about $10 \%$ per annum in recent years in Uzbekistan.

That decline has been accentuated by two other factors. First, spare parts were often unavailable. Under the COMECON system manufacturing capacity was heavily concentrated. Buses came either from Ikarus in Hungary or from a Russian manufacturer. Trolleybuses came from ZIL in Russia or Skoda in Czechoslovakia. Smaller vehicles came from RAF in Latvia. The collapse of the exchange system led to a chronic shortage of foreign exchange in some countries. Furthermore, suppliers requiring 100\% payments in advance of dispatch, though they were offering no delivery or performance guarantees. In Turkmenistan, this had been overcome, though not in a very satisfactory way, through a three way barter deal with Azerbaijan and Iran, from which a supply of Iranian Shahab vehicles was obtained. Under a World Bank project in Turkmenistan a significant initial improvement in bus service was obtained for very little expenditure by obtaining a delivery of Ikarus spare parts.

Second, government policies have sometimes contributed to the cash flow problem. In Uzbekistan the government exercises its legal power to requisition vehicles to take urban population out to harvest cotton and children to summer camps. Payment has usually been delayed by more than six months, and in some cases made in kind (second hand vehicles obtained from other former state industries) rather than in kind. As a consequence, in 1997,

\footnotetext{
${ }^{4}$ In the great depression in the U.S. in the thirties real incomes of those in employment remained stable, with the decline in GDP roughly proportional to the decline in employment. In the FSU almost exactly the opposite has happened, with relatively low rates of total unemployment, but significant losses of real income for those remaining in employment. Milanovic. op. cit.
} 
one of the operating centers in Samarkand only had 160 out of a fleet of 280 vehicles available for service; 50 of the 120 unavailable were off the road for lack of serviceable tires. A year later things got even worse, as arrears on fuel payments led the oil supplier to withhold supply, putting whole fleets out of operation for a period of over a month. This is the vacuum into which private sector supply was drawn from the early 90's on.

\subsection{The response to the crisis}

In all of the countries covered in this paper central government responded to the emerging financial crisis by decentralizing financial responsibility for urban public transport either to oblast or city level. Initially this was not accompanied either by a transfer of the powers to grant concessions or by the installation of adequate inter-governmental transfers to reflect the magnitude of the financial burdens transferred.

A second strand of policy was the corporatization of the enterprises to take them off budget. This took various forms (discussed in more detail below), but, as with decentralization, did not normally involve any element contributing to a solution of the real problems. Not all state parastatals have been converted into joint stock companies. In Uzbekistan some of the parks which have been deemed to have strategic significance have been retained as public "brigades". In Riga, Latvia three enterprises stayed in public ownership after liberalization, and even though a decision had been taken in principle to move them towards privatization the city of Riga, which now owns the enterprises has expressed the desire to maintain them in municipal ownership. Similarly in the Ukraine the major city companies remained in public ownership. In Turkmenistan, while the control has in principle been shifted to the municipal level, in practice the Minister of Transport maintains very close control over the operations of the enterprise in the capital city, Ashgabad.

\section{The emergence of a new private sector}

\subsection{The joint stock company}

The term "private sector" needs to be used with care. Joint stock companies may still be in majority public ownership (for example in Uzbekistan and Kazakhstan), and may not even be subject to a bankruptcy constraint under the national law on state joint stock companies (for instance in Uzbekistan). In some cases in Russia, as in Kurgan, it has taken the form of creating a totally municipally owned joint stock company with $90 \%$ of local market as in Kurgan.

In several countries (Russia, Kazakhstan, Kyrgyz, Uzbekistan) most of the former state enterprises were converted into joint stock companies. But the significance of that step has differed substantially. In Kazakhstan, although the companies still had the state as their majority shareholder immediately after corporatization, the fact that the city enterprises were split in to so many genuinely independent units enabled them to operate with a considerable degree of independence and commercial initiative. In Uzbekistan, in contrast the joint stock companies remain effectively under the control of the regional "obaltrans" organization. The

arrangements vary considerably even within countries. In Kyrgyz, the second city of Osh has five independent, competing companies formed from different parts of the former state system, whereas in Bishkek the Avtokombinat remains stubbornly in municipal ownership, 
having even been consolidated under a single management from the former two separately managed units.

In many Russian cities such as Tosna and Kurushy, formal sector private participation has been achieved through transfer of ownership to employees (sometimes at no cost). In Kyrgyzstan the transfer to employees has in some cases been achieved through the process of coupon auctions purchases. ${ }^{5}$ These companies continue to operate large buses and are often treated as preferred suppliers. In Russia, where the member states of the federation have effective autonomy in the matter in any case, it is the effect of decentralization and withdrawal of federal subsidy which appears to have produced a propensity to innovate to survive independent of whether ownership is genuinely independent or not. In many of the larger cities in Russia the publicly owned enterprises are already established in a number of separate parks which operate largely independently of each other (Novosibirsk has 10, Ufa has 7 and Voronej has 3, all in addition to publicly owned tram and trolleybus enterprises).

Some patterns are discernable. Where the ownership of bus companies has been transferred directly to municipalities, as in Riga and Bishkek the resistance to privatization seems greatest. Similarly, the larger the city the lower in general seems to be the prospect of privatization of the core services, with public enterprises in capital cities particularly well entrenched (e.g. Moscow, Tashkent, Riga, Bishkek, Ashgabad). Finally, although less strongly exhibited, is a tendency for the prospect of privatization to be inversely related to the severity of the financial state of the industry. There is some possibility that well meaning attempts by the multinational banks to assist in resolving the capacity crisis has actually delayed the development of the private sector (e.g. in Riga and some of the Russian secondary cities).

\subsection{The independent operator and operators associations}

Quite distinct from the joint stock companies are what might be called the "independents". For the most part these are very small enterprises or individuals operating microbuses or minibuses. Although private operators do run some large vehicles on central routes in Rostov-on-Don and other Russian cities, in general both the small scale and the position outside the traditional regulatory arrangements has meant that private operators have operated in an uncoordinated and often undisciplined way. Most independent entry is with small vehicles on a small organizational scale, although there are a number of companies operating up to 60 minibuses.

Associations of small operators are beginning to play an important part in the competition for tenders, having been encouraged in some of the countries by the positive actions of the municipalities or the municipal operators. That encouragement has not necessarily been motivated by the desire to build up a viable independent sector competitor, but rather to bring the independents under control, and within the tax net. For example, although in Bishkek, Kyrgyzhstan some private "brigades" had already formed in order to organize schedules, etc.,

\footnotetext{
5 In the process of national economic liberalization in Kyrgyzstan the rights to ownership in the nationally owned assets were allocated in the form of coupons entitling the holders to obtain shares. Individual enterprises were then sold by auction to coupon holders. In some companies the employees combined their coupons to be able to obtain a majority holding.
} 
on routes which had ceased to be operated by the public sector, the municipality itself encouraged the development of a single association, called Liga to assemble as many as possible of the small vehicle operators under a single management. The Transport Coordinator allocated to Liga a number of routes on which the public sector was unable to maintain service. However, as Liga accumulated members (it now has over well over 300) it came to carry more passengers that the public sector carrier and became a threat to it. The municipal carrier therefore established its own affiliate organization to which it attempted to attract Liga members. The Transport Coordinator, the former deputy general manager of the public carrier (Avtokombinat), who continued to be co-located with the general Manager of Avtokombinat, withdrew some permissions from Liga, offering them to the existing carriers so long as they changed allegiance. The outcome of this episode was that Liga appealed to the National Anti-Monopoly Committee, which found in its favor, fining the Transport Coordinator and requiring the licenses to be restored. It is doubtful, however, whether that is the end of the story.

A similar pattern appeared to be emerging in Uzbekistan where the government passed a law enabling the formation of operators associations as part of the reform program to introduce competitively tendered franchising. In Samarkand, the obaltrans then set up an association, providing an administrator, office space and other assistance. However, in response to comments from the World Bank, with whom a public transport loan was being negotiated, and with whose encouragement the competitive system had been introduced, this effort to monopolize was abandoned. In several of the major cities where franchising has been introduced there are now multiple associations, competing for franchises with each other and with the Joint Stock Companies. In one case the association has already begun to provide maintenance facilities and taken other steps in the direction of corporatization. The development of associations in response to announcement of tendering of routes has already started in Russia in some cities such as Ufa.

\subsection{Access to capital}

The collapse of public sector bus supply in the FSU has found its focus in the inability to fund vehicle replacement. Given the depth of the fiscal crisis in all of the FSU countries it is unlikely that the traditional budget source of capital will recover. The long term sustainability of the sector thus depends critically on finding revenue flows which will allow commercial funding of vehicles.

In Kazakhstan the effect of liberalizing the market, assisted by the World Bank loan which financed about 300 new large buses was to increase total capacity. For example the public transport fleet of Shimkent went from 350 full size buses in 1992 to 944 vehicles of many sizes from full size down to 11 seaters in 1999. However, there is now serious concern about the financial survival of the operators. The purchasing power of the public remains low, and many operators believe that the market is now over-supplied.

A few operators are buying new buses, though mini- and midi-buses have been introduced rather than full-size buses. A private operator in Almaty has taken advantage of the Korean financial crisis and bought a small fleet of new Korean midi-buses (20-24 seats). A private operator in Shimkent has acquired 45 new Turkish midi-buses under a purely commercial lease contract with a Swiss lessor. At least one private operator in Karaganda has financed 
new minibuses from Russia through a credit line for small and medium enterprises backed by EBRD. The mini-buses are costing well below $\$ 10,000$ each and the midi-buses $\$ 20-40,000$ each. They match the financial resources of the operators well, and enjoy excellent consumer acceptance for their low cost. The cities no longer need the full-size and articulated buses as much as in the Soviet era, since most of the giant state enterprises have closed; employment centers are now more dispersed and peak traffic hours are less acute.

In other countries the problem may be even more acute. Given the experience with the development of the private sector Government may not consider this sector a priority for sovereign borrowing. Certainly the World Bank view is that buses are assets which should be obtained through normal commercial channels (borrowing or leasing) rather than through sovereign borrowing. But the state of the banking systems in Russia, Kyrgyzstan and Uzbekistan are not favorable to bus financing. Both sides may wish to explore ways to enhance the availability of credit for operators to renew their fleets, by strengthening the banking system and expanding credit supply, reducing risks perceived by private lenders, and hence lowering the cost of credit. Lines of credit for small and medium enterprises or leasing operations may prove helpful and it is hoped that IFC will explore the market for such operations.

\section{The regulatory reforms}

\subsection{Entry to the market}

In some Russian cities such as Kostroma, Suzran and Tosna the former public sector supplier has merely become a joint stock company put at arms length from the political process by a performance agreement between the municipality and the company. The evidence with such performance agreements is generally not very satisfactory. The agreement often fails to specify precisely the municipalities payment obligations, with the result that it works merely as a form of discretionary deficit financing (as in Dmitrovgrad). In some Russian cities, such as Kurgan, the requirements are less clearly specified and the former state enterprise joint stock company has effectively been given a system management contract.

In most countries of the FSU the process of liberalization included a new right of establishment. Licenses to operate public transport vehicles are typically obtainable either through the municipalities (as in Latvia) or through the central agencies (as in Uzbekistan where Uzavtotrans had a licensing agency for private operators despite the fact that it was also the effective owner of the traditional public sector operators). Typically these licenses (the "patent") require a series of certifications (on vehicle fitness, operator fitness, conformity with tax regulations, etc.) and are issued on payment of a fee.

In most cases possession of a patent did not confer any specific route operating rights. Effective entry to the industry thus depended on the further step of finding some place of operation. In most countries this was initially done quasi-legally by operating on the same routes as the public sector operators, often filling in gaps of service where the public sector was unable to field vehicles. Eventually this tended to become formalized. For example, In Bishkek in Kyrgyzstan private vehicles would present themselves to the public sector dispatchers at route terminals and would be allocated to scheduled service when the public sector vehicle did not turn up. Later, the transport coordinator - who was closely involved in 
the operation of the public sector company - granted short (3 month) contracts to individual operators to supplement service on particular routes.

In Riga, Latvia, the private sector was operating 90 large vehicles and 120 small vehicles, carrying $12 \%$ of total passengers in this ad hoc manner by the end of 1997 . But in most other countries new entrants normally operated small vehicles - typically 11 seat RAF minivans. These could be obtained on the second hand market throughout the FSU, at a cost which might be afforded by individuals through pooling family savings, etc. In Kyrgyzhstan vehicles could even be leased from manufacturing enterprises which had formerly provided their own transport services. Given the need for the private sector capacity where whole routes were denuded of public sector vehicles, this was further encouraged by throwing whole routes open to private supply. In addition minibus routes were established in parallel with under-supplied large bus routes, and some new routes were even established by private brigades on their own initiative, but with the tacit agreement of the public operator.

These arrangements tended to develop in a very piecemeal and reactive fashion. This had a number of disadvantages. Firstly, in the absence of any formal scheduling arrangement, it tended to be self regulated through a sort of "tour de role" system in which vehicles queued at the terminal and left in turn as they became fully loaded. This results in long periods of idle time for waiting vehicles, poor accessibility to service for passengers other than at terminal locations, and poor vehicle utilization. Second, it left the private sector with a very insecure living, and certainly without the sort of prospective revenue flow to justify new vehicle purchase. Th incentive to private participation was further accentuated by the arrangements for fare determination, control and exemptions.

\subsection{Fare controls}

It remains the common belief, in all of the countries considered that fares must be controlled in order to protect the poor. Given the failure of many of the other safety nets to which the population is accustomed, that is quite understandable. However, given the decentralization of financial responsibility to the cities, and their lack of funds, there is a discipline emerging. Fare reviews have been undertaken in Uzbekistan, for example, which have resulted in fare revisions at least in pace with inflation.

The traditional fare structure in socialist cities has been a flat fare, although both in Russia and most other countries, municipal routes which also serve the surrounding rayon have crudely distance related fares. Again, given the historic socialist housing and industrial location policies it is easy to understand why governments are loath to introduce more commercially rational pricing policies. But the flat fare policy has given rise to some distortions in route design in Turkmenistan, and is also beginning to be questioned, at least at central ministry level, in Kyrgyzstan.

In many Russian cities, as well as in Uzbekistan and Kyrgyzstan private operators are often given a "cap" which is higher than the municipal fare. Both in the franchising competition in Uzbekistan and in on the road competition in Russia operators may choose to operate below the cap to compete with each other or with the municipal enterprises. More recently in some Russian cities such as Krasnodar there has been the formal establishment of multi-tier fare structures according to exemption obligations and/or vehicle type. In one case, in Novi 
Uregoy in the Arctic region, this is taken to an extreme with a zero fare charged for basic municipal service, and a 5 ruble fare allowed for private operator. In Ukraine the local government (municipality is responsible for issuing an operating license and monitoring the private sector and negotiating the fares with them. Typically the fares are higher for the private operators compare to the public providers. There some exceptions to this. In Ivano Frankivs'k and Ternopil where the public operator is also strong not only the fares are lower for the private operators when compared to fares elsewhere in Ukraine but they are the same as the public operator provided premium service fares. In Ternopil, cross-subsidy from premium services is the basis on which it has been possible for traditional services to be maintained without direct subsidy to the public sector operator.

The differentiation of prices is usually based on vehicle size, with vehicles of capacity less than 16 usually able to charge higher fares than larger vehicles. This occurs even in cases where the vehicles are publicly operated. For example in Riga, Latvia, the state owned joint stock company Riga Taxi Park was at the end of 1997 operating a fleet of 70 minibuses at fares double the standard bus fare. Separate of the former state taxi parks operating smaller vehicles are to be found, usually now in joint stock company form, in many countries. This kind of differentiation has even led more traditional large bus operators to develop their own small vehicle fleets. For example, one of the state joint stock company operators in Samarkand has been able to borrow money to purchase 227 seater Damas vehicles on route service, and finds this to be the only commercially viable part of its whole activity.

So long as service can be maintained, either by direct subsidy or by internal cross subsidy, the efforts to maintain flat, and preferably low, basic fares, can be tolerated. Once service level begins to deteriorate significantly as a consequence of those policies, they should begin to be questioned ever more severely. It is interesting to note, in that context, the difference in views on this matter according to how the question is put. Of course, no-one will admit to a desire to see fares rise, and that is often expressed in terms of "affordability". And that is what is represented in the political rhetoric on the subject. But in social surveys undertaken in connection with World Bank projects in both Uzbekistan respondents have expressed more concern about the quality and availability of public transport service than about its cost. That is also to some extent reflected in the relatively high proportion of passengers who choose to use the faster, more frequent and less crowded, but substantially more expensive minibus services even when a conventional bus could have been used.

Private operators do not normally carry exempt passengers and are not normally in receipt of any subsidy. This is a serious limitation on the scope of competition, as a private operator might well be able to provide the subsidized service more economically than the public enterprise. One of the greatest advantages of moving towards a comprehensive competitive tendering of all franchises, with both negative or positive contract prices possible, is that it extends the benefits of competition across the whole range of services.

\subsection{Exemptions and concessions}

In several countries operators argue that without exemptions public transport could operate commercially. The revision of the exemptions arrangements is therefore high on the list of priorities for reform. 
In Russia, virtually all operators appear to consider it a losing battle in present political circumstances to try to get the federal government to change exemption arrangements, or to force the line ministries for whom exemptions operate to pay directly Therefore great ingenuity is being used in finding ways to circumvent the restraints. The main thrust has been to reduce the proportion of service on which concessions or exemptions are valid. This has been done in a number of ways. Two tier systems of concession carrying and non-concession carrying buses, with same operators, have been introduced with a public operator in Ufa, Suzran, and Barnaul, and with even with a private operator in Veliki Uslug. More commonly private sector operators not carrying exemptions or receiving subsidy operate on the same routes operated with subsidy by the public sector operator (in Narian Mar, Dmitrovgrad, Kursk). Another device used for private sector services in Voronej is to limit the number of concessionary passengers in any vehicle to 1,2 or 3 according to vehicle size. Because it is believed that the requirement to honor exemptions only applies to the public sector, publicly owned vehicles are even being leased to the private sector to run without subsidy in Bratsk. Another part of the problem is that with so many exemptions it becomes difficult to identify who is eligible to pay, especially when the number of exempt categories is so large. The introduction of a standard identification document has been used in Novosibirsk, Krasnodar, and Kursk to minimize this problem.

Despite the difficulties in obtaining either a change in federal law on exemptions, or direct payment for the exemptions from the relevant line ministries or agencies, many cities in Russia do appear to be making serious efforts to put subsidy on a more business like basis. The financing of subsidies is normally done through the general municipal budget. This is currently under great pressure and agreed, contracted, payments are being delayed. But several cities have attempted to overcome this problem by seeking local sources of funding. Ufa has a local special transport tax - $2 \%$ of wage bill. Kostrama uses revenues from private sector concessions. Novi Urengoy levies a special tax on commercial vehicles earmarked for public transport support.

Payments often made on a computed basis, in principle quarterly in arrears (Kurushy), monthly in advance (Baljski) or even daily (Tosno). Some independent calculation of compensation requirement may be made (Kurushy). Even where there is an agreement, however, there may not be a firm contractual limit on the obligation of the parties so that the payment is more like a deficit financing arrangement (Dmitrovgrad). Moreover, given financial difficulties payments are often made in kind through such devices as tradeable tax exemptions (Kanerovo); subsidized fuel to the extent of the calculated obligation (Baljski); or even heated garaging (Krasnoyarsk).

The experience of Kazakhstan demonstrates that the problem of exemptions can be addressed if there is a political willingness to do so. Legislation in 1996 required payment of compensation for free or discount travel by "sponsoring" government agencies (e.g. the Ministry of Defense for soldiers, the Ministry of Education for school children and students, and the social security agencies for pensioners). These agencies have only partly complied because they too lack funds and negotiation continues. Exempt and discount passengers now number less than [20]\% of all passengers. The trend suggests that the situation will stabilize at a point where only school children will continue to enjoy discount fares and all other exemptions will be eliminated. That pattern is being followed in Kyrgyzstan. Although the calculated costs are not completely funded and the procedures for distribution and allocation 
of the compensation has been a matter of dispute in Bishkek, the government is now budgeting compensation for those exemptions which are statutorily the responsibility of central government. That opens up the possibility of addressing all other exemptions in a similar way, requiring the granting authority to take the necessary steps to ensure that they are financed; in the absence of which the concession might cease to honored by the operators.

\subsection{Franchising}

The various impediments to the effective mobilization of independent private sector potential in public transport are now being recognized in many countries and the conditions for their operation revised accordingly. In many cases this has taken the form of the formal franchising systems, often competitively tendered.

In Riga, Latvia the three existing public operators have been corporatized (though they remain municipally owned), and their relationship with the city put on the basis of a performance agreement. The contracts cover schedules, fares, concessionary travel compensation, and are the basis on which subsidy is paid. Although government has declared the ultimate aim is to privatize the companies and phase out the subsidies, city government does not have any great enthusiasm for privatization which has been stalled partly because it appears to be a condition of privatization that the companies are first put into good commercial order, and partly because of problems concerning the rights of ownership of land assets presently occupied by the public companies. In the meantime the average age of the vehicles in operation is about ten years, only about $70 \%$ of the vehicles owned are operational at the peak, and the number of employees per vehicle is about 8 .

Similar interim arrangements of performance agreement or system concession kind also exist in Turkmenistan and a number of Russian cities. In the former, which is one of the least market oriented countries of the FSU, habits of central control die hard, and there is still very strong effective central government control of operations. The performance is even worse than that reported for Latvia.

The first of the countries covered in this review to introduce a competitively tendered franchising system was Kazakhstan. Major decisions by the national and municipal governments shaped the restructuring of the sector. In July 1995 the public transport tax, a tax on the turnover of all companies earmarked for public transport, was abolished as part of fiscal reforms recommended by the IMF and the Bank. By removing a stable source of state budget funds for the sector, this forced the national and municipal transport authorities to find alternative solutions to the problem of free travel and inadequate cost recovery by the bus operating companies.

The major legislation reshaping the sector to adjust to this new reality was Decree 773 of June 1996, which mandated dismantling of the municipal monopoly bus companies, corporatization of the individual municipal bus depots, provision of compensation for major free-travel privileges, and the opening of urban transit markets to the private sector through competitive award of route licenses. All former municipal bus fleets have now been restructured as joint-stock companies and shares distributed or sold to employees, municipalities and private investors in various proportions. The eight such companies in 
Almaty are still majority-owned by the City. The shares of one company in Shymkent are still all owned by the municipality.

Various further legislation has been introduced at national and municipal levels since 1996 to implement these radical new policies, notably regarding design of the route tendering system. Bids for route licenses are compared anonymously on a points system. (Consideration should be given to putting it on the basis of a monetary parameter, such as the lowest average fare, or at least weighting the points more in this direction.) The number of bidders per tender was only one or two in the first rounds in 1997, but reached an average of 3 and a maximum of 10 in Almaty in 1999. In short, the abolition of the public transport tax forced the abandonment of old ways; Decree 773 forced de-monopolization of bus ownership and tendering for route licenses; and the subsequent enabling legislation radically improved operators' opportunities to recover their costs.

Uzbekistan is now following Kazakhstan in the introduction of competitively tendered franchising, but on a rather different structural basis. By the time Uzbekistan introduced its first experiments in franchising in late 1997 the decline of the public sector companies was well advanced, and the private sector was already carrying about $50 \%$ of the passengers in some cities, almost exclusively in small vehicles. On the other hand, though the former state companies had been converted into joint stock companies, as mentioned above, the state remained as the majority shareholder and they had little real commercial independence. Until very recently they continued to pay a levy of $3 \%$ of their turnover to the oblast agency of the former state enterprise (the "obaltrans"), having formally changed the status of that contribution from being a levy to being a "voluntary contribution for coordination services levied". Nevertheless, the government has moved to ensure the completion of the tendering process in the initial experimental cities by this year, and intends to extend the requirement for all urban services to be put to competitive tender.

As far as the minibus routes are concerned there is already considerable evidence to indicate that the competition is genuine. After a first round of tenders using highly qualitative criteria largely replicating those used in Kazakhstan, it has now passed a law requiring the fare charged to the passenger to be the main criterion of choice (although it is not yet clear that the mechanics of the process actually achieve that). But fares for the minibus services have fallen, and the quality of service appears to have improved. However, the Achilles heel of the system appears to be the fact that by designating routes as either small bus routes or large bus routes, in circumstances where only the Joint Stock Companies are operating large vehicles, the regulatory authority, still largely dependent on the oblastrans for its technical advice, may be acting in such a way as to protect the JSC's interests. There is a "catch 22" here. Until the franchising system has been seen to be stable and reliable, and contracts are trusted both by the independent operators and the Banks, independent operators are unwilling to take on the obligations of large vehicle ownership or leasing, and the financial system is unwilling to lend for it. If, however, the World Bank lends to government which then on-lends exclusively to the Joint Stock Companies, there will be no effective competition for the core services. For that reason a range of alternative channels of finance are being considered to try to ensure that in the process of assisting to overcome the short term problem of inadequate supply of conventional buses the Bank does not undermine the further development of the competitive system that it was largely instrumental in introducing. 
In Kyrgyzstan central government supports the idea of competitive tendering of franchises, and has engaged consultants under a World Bank project preparation grant to advise on the development of a system. The secondary cities already have completely privatized operations, usually with multiple operators. For example, in Osh there are two completely independent enterprises formed from the former bus company as well as several smaller companies operating minibuses and a large association of independent minibus operators. The city allocation of operating rights to these companies has been a controversial issue for the city authorities, so that the introduction of a formal competitive tendering regime is generally welcomed. In Jalalabad, a much smaller city, there are two main operating groups, one formed from the old public sector operator and one an operators association developed by the city to offer competition. Only the former presently operates large vehicles, though the coordinator is attempting to interest operators from outside the city in bidding for contracts under the intended future regime.

The situation is much less promising in the capital city, Bishkek. There the public bus enterprise, the Avtokombinat, is in dire financial straits and faces rapid decline of its operating assets. Two thirds of the base fare passengers are actually carried by the publicly owned, but totally separate, trolleybus enterprise. Nevertheless, the Avtokombinat retains a strong control over the city transport coordination function. Revenues both for compensation for carriage of exempt passengers and revenues from season ticket sales are distributed in ways which strongly favor Avtokombinat, and route operating permissions have also been manipulated in ways designed to bolster the core public sector bus operator. Any development of a competitive tendering arrangement would be unlikely to be successful in that climate unless it were possible to create a totally independent procurement function, and to set up the franchising competition on a clearly objective basis.

The situation in Russia is also very fragmented. It is now common for the municipal transport authority to be formally at arms length from the operating enterprises. However, there is a very wide range of arrangements linking the two. Performance agreements between city authority and quasi independent, but municipally owned, operators are most common (Kostroma, Suzran), and similar single source negotiated contracts exist with formerly state owned joint stock company (Tosna). Even where there are multiple formal contractual relationships between the municipal authority these are not yet usually subject to effective competition. Open ended contracts, with automatic renewal subject to good behavior are common and found in cities such as Veliki Uslug, Ulan Ude, Narian Mar, and Barnaul. In a number of cities franchises are sold, but on a non-competitive basis; This may be at a fixed price payment per month for route franchise by private operators as in Ulan Ude, and Tomsk or the payment may be related to the size of the vehicle franchised. As the franchises sold in this way do not normally carry any obligation to carry exempt passengers, this might reasonably be viewed as an embryonic form of comprehensive competitive tendering.

In a number of cities (Rostov, Krasnoyarsk, Bratsk, Kursk, Voronej) the principal of competition for franchises has been adopted. But so far the criteria are usually essentially qualitative. This has the disadvantage that it does not really exploit the main advantage of the private sector, namely its ability to provide a given service at a lower price than the traditional public sector operator. There is a further danger, exemplified in Rostov and Voronej that the criteria chosen reflect traditional public sector input processes (medical inspection arrangements, maintenance scheduling) rather than the outputs required by the 
customer (safety, reliability, affordability, etc). Normally the tender authority is the city, though the tender committee may represent a number of interests as in Rostov, and Voronej. However, where the criteria are of the traditional qualitative kind and the members of the commission are from the traditional public sector background, there is likely to be a serious bias in favor of the traditional, "preferred" operators.

Where competitively tendered franchising has been introduced this is mostly on a net cost basis (Veliki Uslug, Rostov, Tomsk - this year, Ufa, Suzran - next year, Nalchik, Bobovich). This probably reflects the absence of adequate and secure revenue collection systems, rather than any conscious preference for the allocation of revenue risk to the franchisee. In only one case of the cities responding (Kursk) is operation separated from fare collection in what looks like a gross cost arrangement the system is monitored by AVL and there is a penalty and incentive system for on-time performance. Non of the other cities with multiple modes has yet introduced a common pricing or ticketing arrangement for which gross cost franchising would be most appropriate.

One of the problems which remains to be resolved in most of these fledgling competitive tendering regimes is what to do about "pirate" operation. In Uzbekistan successful implementation of competitive tendering of minibus routes has been based on fairly energetic enforcement of the route monopoly rights awarded. In contrast, in Kazakhstan the franchised operators of large bus routes have been subject to unrestricted competition from independent small vehicle operators. So long as bus fares are controlled and minibus fares are significantly higher than large bus fares, and the large vehicle operators receive some sort of indirect compensation in the form of provision of rolling stock for which they have not paid the full capital costs, that has been sustainable. But the long term problem of how vehicles are to be financed is now beginning to cause concern, and it is likely that the differential between fares will narrow. While the government has decided, in principle, that the franchised routes are not to be subject to unlicensed competition, enforcement of that decision appears to be weak.

\section{Prospects for the future}

Privately owned buses already carry the majority of bus passengers in Russian secondary cities and in Kyrgyzstan, probably about half in Uzbekistan, and a growing proportion in all other countries except Turkmenistan. In Kazakhstan, where some of the competing companies still have majority state ownership the process of privatization is likely to be taken to completion in the near future. That trend, which merely reflects the ownership structure trends world wide is unlikely to be reversed. Only in Latvia, Turkmenistan and Ukraine is there strong resistance to this trend. But that is not to say that the current situation is stable or sustainable. The threats to that sustainable development can be grouped either by country or by issue.

\subsection{The country prospects}

In the cities of Kazakhstan where competitive tendering was introduced earliest, fares are still controlled at levels which do not appear to be consistent with the quality of vehicles and quantity of service which the franchisers are calling for. For example, it has been estimated that the revenues being obtained from the vehicles purchased under the World Bank loan, are 
barely sufficient to meet the servicing and debt retirement costs of the vehicles alone. ${ }^{6}$ Either fares will have to be increased significantly or the expectations of vehicle quality or service quantity revised downwards to a significant degree.

In Uzbekistan private sector has been very extensively mobilized to fill the holes left by the decline of the former public sector. But they have not yet entered into the supply of core services in conventional buses, and the vehicle which they have been able to finance, the Daewoo Damas is very unsuitable as a core passenger carrier. The franchising system thus needs considerable further development, and the incentives to supply larger vehicle services considerably increased before a stable future can be assured. That requires developments both in the franchising regime and the development of new channels of vehicle finance.

In Kyrgyzstan the capital city, Bishkek, is probably the least reformed and the worst supplied in the region. The bulk of the main route demand is carried by the trolleybus enterprise, which appears to be relatively efficient, but cannot justify any significant expansion of its infrastructure network to take over the conventional bus role. For smaller cities, exemplified by Osh and Jalalabad in Kyrgyz, the problem of financing large vehicles is less of a problem. Indeed, there is probably more benefit to be obtained by investing in rehabilitating the desperate state of the urban road network, and leaving vehicle purchase to the private sector than, in attempting to re-establish the public sector buys fleet.

In Russia, the problem of establishing a stable regulatory regime within which the private sector can be further developed remains to be solved. Certainly the division of function between publicly owned operators providing subsidized basic services while the private sector supplements the supply with premium services is not an efficient mobilization of private sector potential. Despite the ingenuity being shown in evading fare constraints, and the initiative shown in developing franchise arrangements in some cities, a much more thorough going reform is required.

In Latvia, despite very poor operating performance of the public companies, and an average yield per passenger for private enterprises roughly double that of the public companies, the private sector still supplies less than $15 \%$ of the market, and is not growing as rapidly in other countries. That appears to be explained largely in terms of the continued commitment of the city to its municipally owned organizations and the absence of any secure regulatory framework for the private sector organizations. Support from multilateral Banks has been channeled exclusively to the public sector organizations. No serious attempt has been made to stimulate private operation or competition; indeed serious consideration has been given to merging the two bus operations to "reduce overheads". The fact that they still operate in deficit implies that subsidy is similarly being channeled exclusively through the old public sector operators.

In Turkmenistan, the prospects for the private sector still look bleak. A World Bank project has involved the formal separation of system management from operations, but in practice

${ }^{6}$ World Bank. ICR on the Kazakhstan Urban Transport Loan 
there is little real separation. Funds have been channeled to the publicly owned enterprises, albeit now formally municipal.

In Ukraine, private sector operators entered the market as a result of governments ability to respond to the demand due to deteriorating fleets and inability to replace them. Private provision of transport services was first introduced through, a USAID project in 1994, and in subsequent projects funded by USAID, more work was done to encourage local governments to allow private operators to enter the market. To a great extent out of desperation this took off, and as in other FSU countries mostly minibuses were used. In many cities up to $50 \%$ of the service is now provided by the private sector. The success of private sector development augurs well for further development despite the absence to date of a secure regulatory context for the development.

\subsection{The generic issues}

The first issue affecting the prospects for the private sector participation is the form of regulatory regime that develops. So long as there is no reliable, fairly long duration, franchise contract available the private sector will only find it attractive to supply public transport services with old or small vehicles which can be readily disposed of, and for which the capital commitment is small. Similarly, even if there is a competitively tendered franchising system private capital is only likely to be committed if there is thought to be a level playing field. If governments are perceived to favor incumbents then new entry will be attractive. The most critical issue therefore is that government is seen to have strong commitment to private participation, best demonstrated by divestiture of all public sector operating facilities.

The second issue is related to the first. Any franchise contract must be seen to be potentially profitable. Thus both fare levels and compensation for exemptions must either be set at levels which make remunerative operation possible or there must be negative price franchises. In either case, the commitment of government not to intervene to change the terms of contract, and to honor its obligations under the contract must be worthy of the respect of potential private suppliers. One possible way of handling that in the early days of new regimes might be through some international guarantee mechanism. The World Bank has an instrument which might well be used for this purpose.

The third issue concerns the degree of understanding of the potential for competition and the role of the multilaterals in encouraging that. Where the multilaterals have been willing to put finance in to the old public sector operations, as in Turkmenistan, Latvia and the Russian secondary cities, the emphasis has been on tinkering with various aspects of the efficiency of the traditional operators (route restructuring, improved fare collection, improved maintenance arrangements, etc., and little effort has been made to introduce fundamental reforms. Simply requiring improved farebox cost recovery as a condition for investment has had some immediate impact on the level of cost recovery. But this does not look to have been well sustained (for example in Russia and Turkmentistan). More significantly, it has not brought the public operators into a financially sustainable state, so that the fundamental problem remains unresolved. Where the multilaterals have put much more emphasis on explaining the reform possibilities, and in some cases made financial support conditional on reform, more has been achieved (for example in Uzbekistan). 
Finally there is a question about vehicle finance. In most countries buses can either be leased or bought and sold on secondary markets. Given a potentially profitable market finance is not a serious constraint. That is not necessarily the case in the FSU. Manufacturers may be unwilling to enter into leasing agreements, even full service leasing contracts, unless they can be assured that vehicles will be well maintained. And to do that they may require to provide the maintenance directly or have very strong control over performance. Setting up the facilities to do that is expensive and risky, and may require a minimum size of market to attract participation. Mercedes do that in Tashkent, and it is common in many other countries (for example Bangkok Metropolitan Transit Authority has most if not all of its fleet of airconditioned vehicles on full service leases) but it may be difficult to achieve in smaller and newer markets. Even the development of an effective local secondary market for vehicles may be difficult to achieve in some countries. Hence to assist the development of private sector participation in the core, rather than the small vehicle, small operator fringe of the market, it is necessary to have a strong financial sector as well as a strong public transport regulatory and procurement function. 